Louisiana State University

LSU Digital Commons

Faculty Publications

Department of Biological Sciences

$4-1-2004$

\title{
Conserving slow-growing, long-lived tree species: Input from the demography of a rare understory conifer, Taxus floridana
}

Charles Kwit

Louisiana State University

Carol C. Horvitz

University of Miami

William J. Platt

Louisiana State University

Follow this and additional works at: https://digitalcommons.Isu.edu/biosci_pubs

\section{Recommended Citation}

Kwit, C., Horvitz, C., \& Platt, W. (2004). Conserving slow-growing, long-lived tree species: Input from the demography of a rare understory conifer, Taxus floridana. Conservation Biology, 18 (2), 432-443.

https://doi.org/10.1111/j.1523-1739.2004.00567.x

This Article is brought to you for free and open access by the Department of Biological Sciences at LSU Digital Commons. It has been accepted for inclusion in Faculty Publications by an authorized administrator of LSU Digital Commons. For more information, please contact ir@lsu.edu. 


\title{
Conserving Slow-Growing, Long-Lived Tree Species: Input from the Demography of a Rare Understory Conifer, Taxus floridana
}

\author{
CHARLES KWIT, ${ }^{*} \ddagger$ CAROL C. HORVITZ,$\dagger$ AND WILLIAM J. PLATT ${ }^{*}$ \\ ${ }^{*}$ Department of Biological Sciences, Louisiana State University, Baton Rouge, LA 70803, U.S.A. \\ †Department of Biology, University of Miami, Coral Gables, FL 33124, U.S.A.
}

\begin{abstract}
Although land preservation and promotion of successful regeneration are important conservation actions, their ability to increase population growth rates of slow-growing, long-lived trees is limited. We investigated the demography of Taxus floridana Nutt., a rare understory conifer, in three populations in different ravine forests spanning its entire geographic range along the Apalachicola River Bluffs in northern Florida (U.S.A.). We examined spatial and temporal patterns in demographic parameters and projected population growth rates by using four years of data on the recruitment and survival of seedlings and established stems, and on diameter growth from cross-sections of dead stems. All populations experienced a roughly 10-fold increase in seedling recruitment in 1996 compared with other years. The fates of seedlings and stems between 8 and $16 \mathrm{~mm}$ differed among populations. The fates of stems in two other size classes (the 2- to 4-mm class and the 4- to 8-mm class) differed among both populations and years. Individual stems in all populations exhibited similarly slow growth rates. Stochastic matrix models projected declines in all populations. Stochastic matrix analysis revealed the high elasticity of a measure of stochastic population growth rate to perturbations in the stasis of large reproductive stems for all populations. Additional analyses also indicated that occasional episodes of bigh recruitment do not greatly affect population growth rates. Conservation efforts directed at long-lived, slow-growing rare plants like Taxus floridana should both protect established reproductive individuals and further enhance survival of individuals in other life-history stages, such as juveniles, that often do not appear to contribute greatly to population growth rates.
\end{abstract}

Key Words: elasticity analysis, environmental stochasticity, episodic recruitment, matrix population models, population dynamics, spatial and temporal variation

Conservación de Especies Arbóreas de Crecimiento Lento y Longevas: Insumos de la Demografía de una Conífera de Sotobosque Rara, Taxus floridana

Resumen: Aunque la preservación de tierras y la promoción de regeneración exitosa son acciones de conservación importantes, su capacidad para incrementar las tasas de crecimiento poblacional de árboles longevos de crecimiento lento es limitada. Investigamos la demografía de Taxus floridana Nutt, una conífera de sotobosque rara, en tres poblaciones en diferentes bosques de cañada abarcando todo su rango de distribución a lo largo del Río Apalachicola en el norte de Florida, (E.U.A.). Examinamos los patrones espaciales y temporales de parámetros demográficos y las tasas de crecimiento poblacional proyectadas utilizando cuatro años de datos sobre reclutamiento y supervivencia de plántulas y tallos establecidos, y en el diámetro de crecimiento de secciones transversales de tallos muertos. Todas las poblaciones presentaron un incremento general de 10 veces en el reclutamiento de plántulas en 1996 en comparación con otros años. El destino de plántulas y tallos de 8 a 16 mm difirió entre las poblaciones. El destino de tallos en otras dos clases de tamaño (2- a 4mm y 4- a 8- mm) fue diferente entre ambas poblaciones y entre años. Los tallos individuales en todas las

‡Current address: Savannab River Ecology Laboratory, P.O. Drawer E, Aiken, SC 29802, U.S.A., email kwit@srel.edu Paper submitted December 30, 2002; revised manuscript accepted July 16, 2003.

432 
poblaciones exhibieron tasas similares de crecimiento lento. Los modelos matriciales estocásticos proyectaron declinaciones en todas las poblaciones. El análisis de matrices estocásticas reveló una alta elasticidad de una medida de tasa de crecimiento poblacional estocástica a perturbaciones en el estado estático de tallos reproductivos grandes en todas las poblaciones. Los análisis adicionales también indicaron que episodios ocasionales de alto reclutamiento no afectan significativamente las tasas de crecimiento poblacional. Los esfuerzos de conservación dirigidos a plantas raras, longevas y de crecimiento lento como Taxus floridana deben proteger tanto a individuos reproductivos establecidos e incrementar la supervivencia de otras etapas de su bistoria de vida, como los juveniles, que a menudo no parecen contribuir a las tasas de crecimiento poblacional.

Palabras Clave: análisis de elasticidad, estocacidad ambiental, modelos poblacionales matriciales, reclutamiento episódico, variación espacial y temporal

\section{Introduction}

Populations of slow-growing, long-lived plants typically receive little attention in conservation plans. Populations of such species do not often undergo marked declines, and even populations with little or no regeneration are projected to survive for decades to centuries (Stephenson 1994; Schwartz et al. 2000; Zuidema \& Boot 2002). Two empirically based, general conservation strategies have been applied to slow-growing, long-lived species that are rare or endemic to small geographic areas. First, most plans for management of such species have focused on land protection, with the goal of protecting established individuals (Roovers \& Rebertus 1993; Cardel et al. 1997). The rationale has been to maintain high survival of established individuals that might reproduce and whose survival has the greatest effect on population growth rates (Silvertown et al. 1993). In addition, to a lesser extent, conservation efforts have focused on the reinstitution of ecological processes important in recruitment of new individuals (e.g., fires in old-growth stands of conifers; Stephenson 1996; Platt 1999). The goals of efforts to promote successful regeneration are new recruits and increased genetic diversity (Frankel \& Soulé 1981; Barrett \& Kohn 1991).

These two conservation strategies may not be sufficient by themselves if populations of slow-growing, long-lived plants are predicted to be in long-term declines. Elasticity analyses, thought to identify important life-history transitions meriting attention (Schemske et al. 1994; Benton \& Grant 1999), typically reveal that changes in stasis (survival without changing stage) of mid-sized to large reproductive individuals have the greatest effects on population growth rates of slow-growing, long-lived plants (Enright \& Watson 1991; Busing \& Spies 1995; Abe et al. 1998; Batista et al. 1998; Zuidema \& Boot 2002). Although mid-sized to large individuals might thus be targets of conservation actions, attempting to augment stasis may have limited usefulness (Silvertown et al. 1996; de Kroon et al. 2000). Mid-sized to large individuals are already likely to have high survival rates with very low temporal variation, their mortality is likely stochastic and uncontrol- lable, and positive manipulation of stasis is likely to be difficult. Reintroduction of ecological processes necessary for regeneration might be required for maintaining populations in decline, but prospective analyses indicate that increased regeneration per se may not be sufficient to result in increased population growth of a declining species. Targeting other life-history transitions might result in sustainable populations, but which of these, if any, might reverse population declines is unknown.

We addressed questions related to conservation of a slow-growing, long-lived tree species, Taxus floridana Nutt. (Taxaceae). This understory conifer is highly restricted in its distribution, being endemic to mature hardwood ravine forests of the Apalachicola River Bluffs region of northern Florida (U.S.A.) (Redmond 1984; Platt \& Schwartz 1990; Kwit et al. 1998). As a result, this species is considered globally rare (sensu Rabinowitz 1981; Rabinowitz et al. 1986) and endangered in the state of Florida (U.S. Fish and Wildlife Service 1981). Over a 4-year period, we examined the survival, growth, and recruitment of $T$. floridana in three ravine forests, spanning its geographic range. We then used the demographic data to construct transition matrices and stage-based Lefkovitch matrix models to project the growth of the different $T$. floridana populations over time. Our results form the basis for proposed conservation actions for T. floridana and may be applicable to other long-lived tree species thought to be in a slow decline to extinction.

\section{Methods}

\section{Study Site}

Hardwood ravine forests of the Apalachicola River Bluffs region of northern Florida occur along creek drainages on the east side of the Apalachicola River in Liberty and Gadsden counties. These ravine forests are typically separated by sandy clayhill and sandhill uplands that historically contained longleaf pine (Pinus palustris Mill.) savannas (Platt 1999). Soils of hardwood ravine forests change from Miocene sandy clays in gully-eroded ravines north of 
the Cody Scarp to Pleistocene sands in steepheads south of this escarpment (Means 1975; Platt \& Schwartz 1990).

The vegetation of hardwood ravine forests of the Apalachicola River Bluffs closely resembles that of other hardwood forests throughout the southeastern coastal plain (Marks \& Harcombe 1981; Platt \& Hermann 1986; White 1987; Batista \& Platt 1997). This area also contains a number of disjunct and endemic species (Platt \& Schwartz 1990) and is considered an important paleorefugium (sensu Nekola 1999). A high diversity of deciduous and evergreen species comprises both the overstory and understory (Platt \& Schwartz 1990). The overstory is dominated by Quercus sp. and Carya sp. on upper slopes, by Fagus grandifolia Ehrh. and Magnolia grandiflora $\mathrm{L}$. on midslopes, and by Magnolia virginiana L. and Nyssa biflora Walt. on lower slopes (Clewell 1986; Kwit et al. 1998). The understory contains a variety of small trees and shrubs, including two endemic species of the family Taxaceae, Torreya taxifolia Arn. (Schwartz \& Hermann 1993, 1999; Schwartz et al. 1995) and our study species, Taxus floridana Nutt. Ex Chapm. (Kwit et al. 1998). The herbaceous ground layer is sparse but increases and becomes more developed from south to north across the Cody Scarp.

Scattered and subdivided populations of T. floridana occur along lower and middle slopes only in the hardwood ravine forests of the Apalachicola River Bluffs. Populations are often referred to by the name of the ravine system where they are found, and will be referred to as such hereafter. Taxus floridana is a dioecious, evergreen conifer that commonly occurs with other evergreen understory species, such as Ilex coriacea (Prush) Chapm. Ilex opaca Ait. and Kalmia latifolia L.(Kwit et al. 1998). Although T. floridana occasionally occurs at densities around $1000 \mathrm{stems/ha,} \mathrm{little} \mathrm{establishment} \mathrm{of} \mathrm{new} \mathrm{T.} \mathrm{flori-}$ dana stems via sexual reproduction or clonal growth (see Redmond 1984) occurred in any population during the decade prior to our study (C. K. \& W. J. P., personal observation).

\section{Data Collection}

We established six study plots (each approximately 0.25 ha), two in each of three ravine systems, in June 1995. From north to south, two plots each were located along a tributary of Rock Creek in Torreya State Park north of the Cody Scarp (hereafter, the Rock Creek population), along Long Branch in a privately owned section of land just north of the Cody Scarp (hereafter, the Long Branch population), and along tributaries of Beaverdam Creek in The Nature Conservancy's Apalachicola Bluffs and Ravines Preserve south of the Cody Scarp (hereafter, the Beaverdam Creek population). Plots were characterized primarily by closed canopy, and no major canopy disturbance took place during the study. All plots were located in areas containing at least 100 stems/0.25 ha, including seedlings.

Within each plot, all T. floridana stems were tagged and measured for basal diameter and height. At the onset, approximately 2300 stems were tagged. We conducted annual censuses in 1996 through 1999 during late May and early June, the period coinciding with completion of seed germination, to record the appearance of new seedlings (hereafter recruitment), their subsequent survival, and the survival of stems tagged at the outset. We recorded survival of larger, nonseedling stems (hereafter, established stems) in five of the study plots; severe erosion in one Long Branch plot precluded annual censuses of older stems.

Due to potential sampling error in yearly diameter measurements of tagged, slow-growing T. floridana stems, growth rates of T. floridana stems were estimated from cross-sections of dead standing stems with intact bark from each of the three ravines. Thirty cross sections of various sizes, 10 from each ravine, were cut at the base of each dead stem. We sanded cross-sections and measured widths of annual rings with a Henson tree ring analyzer (0.01-mm resolution) at the U.S. Geological Survey National Wetland Center in Lafayette, Louisiana (U.S.A.).

\section{Demographic Patterns and Analyses}

\section{STAGE CLASSIFICATION}

We used stems classified by life-history stage and stem size to construct a life-cycle graph (Fig. 1) and define state variables for matrix models of population dynamics. Seedlings were defined as young stems that were nonwoody, green, and $<2 \mathrm{~mm}$ in diameter at the base of the stem. Plants needed about 3 years after germination to reach 2-mm diameter (C. K., personal observation). We classified seedlings into three separate age classes; thus, seedlings either died or entered the next class each year. We assumed that seedlings tagged at the inception of the study in 1995 had recently germinated and thus formed a 1995 cohort because, for the few that survived, woody tissue and a diameter of $2 \mathrm{~mm}$ were not observed until 1998. We defined all stages other than seedlings by exponentially increasing stem-size classes of 2-4, 4-8, 8$16,16-32,32-64$, and $\geq 64 \mathrm{~mm}$, inclusive of the lower bound of the interval. Within stem-size classes, individuals died, survived within, or grew into the proceeding stage by the next census. Only stems $>16-\mathrm{mm}$ diameter produced strobili, so only the three largest stage classes were considered to reproduce sexually.

\section{RECRUITMENT}

To determine whether seedling recruitment varied among ravines or among years, we performed repeatedmeasures analysis of variance, with main effects of ravine 


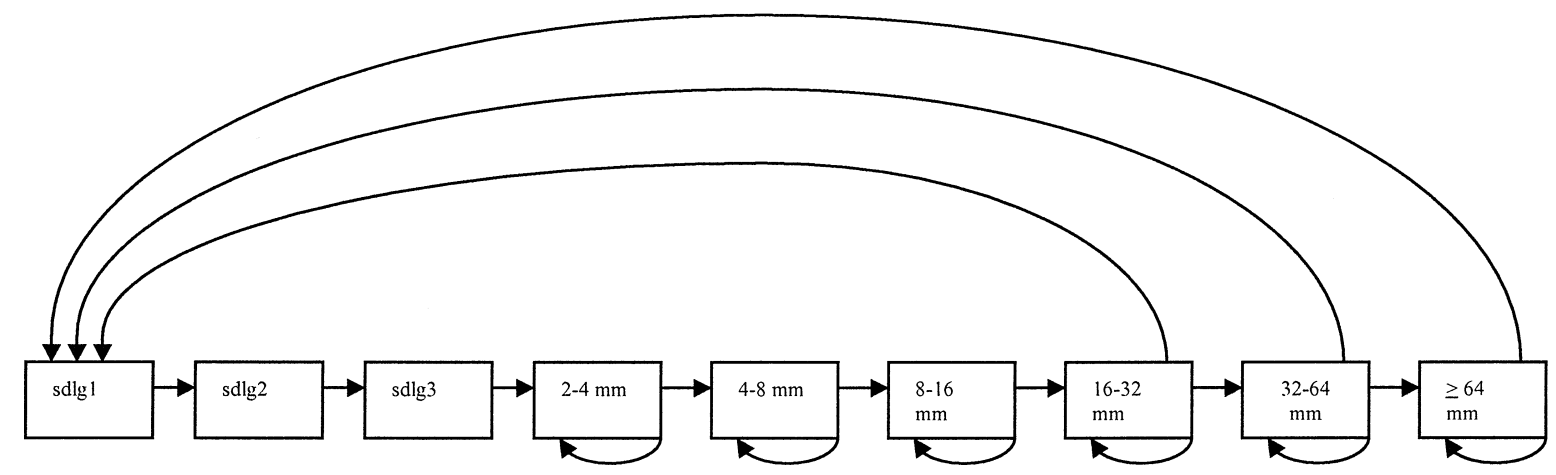

Figure 1. Life-cycle graph of Taxus floridana stem demography. Nodes represent stages, and arrows represent transitions between stages. Seedlings are divided into three separate stages (sdlg1, sdlg2, and sdlg3) to account for age structure. Other stages are dependent on size and are based on basal diameter.

and year and including corresponding interaction effects. The dependent variable, the number of new seedlings in each plot, was natural log-transformed to improve normality. To standardize seedling emergence by seed production in each plot, the summed 1995 log-transformed basal area $\left(\mathrm{mm}^{2}\right)$ of reproductive $T$. floridana stems in each plot was used as a covariate. We assumed that seed production (which was not directly measured) was proportional to the basal area of reproductive stems (e.g., Huenneke \& Marks 1987). We performed this analysis using the Mixed procedure in SAS. To determine which ravines and/or year differed, we made a posteriori comparisons with appropriate contrasts and Tukey-Kramer pair-wise comparisons.

\section{FATES OF STEMS}

We used log-linear analyses (Agresti 1990, 1996) to determine whether the fate of stems-survival or mortalityin each stage class differed among ravines and years. For each stage separately, we first fit a null model predicting that the fate, $F$, of individual stems was independent of ravine, $R$, and year, $Y$, given the preset distribution of individuals in ravines and years: $\log m_{i j k}=u+u_{R(i)}+u_{Y(j)}$ $+u_{F(k)}+u_{R Y(i j)}$, which can also be noted as $(R Y, F)$. To test for the effect of ravine on fate, we fit an expanded model $(R Y, R F)$, which included the term $u_{R F(i k)}$ added to the previous model. The difference in $G^{2}$ between the null $(R Y, F)$ and expanded $(R Y, R F)$ models was used to test for the effect of ravine. We used a similar approach with the difference in $G^{2}$ between the null $(R Y, F)$ and an expanded model incorporating the effect of year $(R Y$, $Y F)$ to test the effect of year. Due to limited sample sizes, seedling fate pertained to the first-year fates of each cohort. Analyses of fates of stems in all other stage classes were based on data from annual censuses.

\section{STEM GROW'TH}

We tested the effect of ravine on the growth of stems over time. Using tree-ring data, we modeled the diameters of individual stems as a linear function of age through the first 60 years (when applicable) by using random coefficient regression, in which regression coefficients are assumed to be a random sample from a population of possible coefficients from independent subjects (Littell et al. 1996). The final 10 years of growth in each stem were not included in this analysis to avoid the possibility of including growth patterns that may contribute to mortality (e.g., slow growth just prior to death of a stem). The general form of the model is: $y_{i j}=a_{i}+x_{i j} b_{i}+e_{i j}$, where $y_{i j}$ is the diameter at age $j$ of the stem $i, a$ is analogous to an intercept coefficient, $b$ is analogous to a slope coefficient, $x$ refers to age, and $e_{i j}$ is a normally distributed error term with mean 0 and an estimated variance. To test whether growth rates were affected by ravine, an interaction term $x_{i j} R_{k} c_{i k}$, analogous to a slope adjustment, was included in an expanded model, and an $F$ test was used to test its significance. We used such a modeling approach to estimate stem growth rates ( $\mathrm{mm}$ /year; i.e., a slope coefficient), depending on which model best fit the data.

\section{Stochastic Matrix Models}

Twelve annual population projection matrices ( 4 transition years for each of the three ravines) were constructed to model the dynamics of $T$. floridana populations. We treated ravines as populations because of methodological and sample-size limitations in some plots and the impossibility of ascribing certain demographic data (e.g., stem growth rates) to plots within ravines. For each population (Rock Creek, Long Branch, Beaverdam Creek), each annual model was represented by a transition matrix, $\mathbf{A}_{t}$, with matrix elements, $a_{i j}$, describing the transition rates of individuals from stage $j$ at time $t$ to any stage $i$ at time $t+1$. Matrix elements representing fertility (top row), stasis (diagonal), and growth (subdiagonal) were parameterized according to the results of the demographic analyses outlined above. The vital rates were given different values 
in the individual matrices, $\mathbf{A}_{t}$, if time and/or ravine significantly affected demographic properties; otherwise, data were pooled accordingly. This approach, as opposed to incorporating all possible temporal variation, had a minimal effect on estimated population growth rates (absolute differences for each population were $<0.003)$. Details concerning matrix elements are outlined below.

We made several assumptions about reproduction and seed fates that have been used in other studies of understory tree demography (e.g., Busing \& Spies 1995): there is no long-lived seed bank; dispersal into a plot is balanced by dispersal out of a plot; seedling emergence is directly proportional to seed production; and seed production is based solely on adult size. Thus, fertility, which in our study referred to seedling production, was assumed to be proportional to the diameter of reproductive adult plants, and its entries reflect a "per-diameter" contribution to reproduction (Huenneke \& Marks 1987).

Stasis and growth entries were determined by combining data on the fates of stems with analyses of stem growth. To determine growth entries for seedlings, we used maximum-likelihood estimates of first-year seedling fates based on the log-linear analyses, and we assumed that for any given annual matrix, seedling growth transitions were similar across all three seedling age classes due to sample-size limitations. To determine stasis and growth entries of nonseedling stems, we combined census data on survival with growth data obtained from analyses of dead stems. We first estimated stage duration, $T_{i}$, via inverse prediction (Neter et al. 1990) from analysis of diameters of individual stems as a function of age. The probability of growth of surviving stems in stage class $i$ into the next stage class, $\gamma_{i}$, was estimated as a function of the annual probability of survival in stage $i, \sigma_{i}$, and of stage duration, $T_{i}$ (Caswell 2001:160-161). Growth and stasis matrix entries for each nonseedling stage were then calculated as $\sigma \gamma$ and $\sigma(1-\gamma)$, respectively.

Our approach allowed for incorporation of temporal demographic variation with the underlying assumption that some elements within annual matrices were likely correlated and not independent and that entries among years might not necessarily be described by continuous distributions from which samples could be drawn. Although our approach incorporated a relatively short period of study ( 4 years), it captured substantial spatial and temporal variation in demographic parameters and provided sufficient and accurate depictions of population dynamics.

For each population, a series of 4000 matrices, each chosen at random (equal probability) from the four annual population matrices, was applied to an initial population vector to incorporate environmental stochasticity. The initial 1000 iterations were discarded to remove initial transient behavior. For each population, stochastic growth rate $\left(\log \lambda_{s}\right)$ and $95 \%$ confidence intervals, time to extinction (or quasi-extinction, $T_{q}$, based on populations falling to $1 / 1000$ of their original size), and the elasticity of $\lambda_{s}$ to infinitesimally small and proportionally equal changes to individual transition matrix elements were calculated based on definitions provided by Caswell (2001). Simulations and calculations for this and subsequent post hoc analyses were performed with the program MATLAB (MathWorks 2001).

\section{Results}

\section{Demographic Patterns}

\section{RECRUITMENT}

The number of new Taxus floridana seedlings differed among years (Fig. 2). Numbers of new seedlings were greatest in 1996, lower in 1997 and 1998, and lowest in 1999 (Fig. 2); these differences produced a highly significant year effect $(F=100.94, p<0.0001)$. New seedling numbers in 1996 were significantly higher than all other years (a posteriori contrast, $F=270.50, p<0.0001$ ) and approximately one order of magnitude greater than the average of the subsequent 3 years. Effects of the covariate (basal areas of reproductive stems; $F=0.56, p=$ $0.5317)$, ravine $(F=4.65, p=0.177)$, and interaction between ravines and years $(F=1.80, p=0.2057)$ were not significant.

\section{FATES OF STEMS}

Fates of stems in reproductive stage classes were independent of ravine and year, but fates of stems in smaller stages exhibited spatial and/or temporal differences. Fates

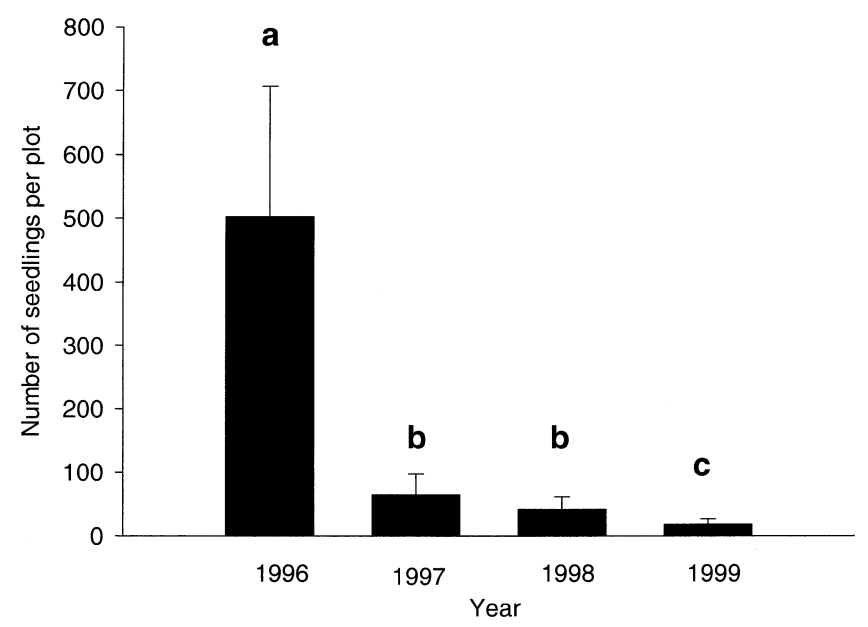

Figure 2. Number of Taxus floridana seedlings per plot (each approximately 0.25 ha) in each of the four censuses. Letters represent significant $(\mathrm{p}<0.05)$ yearly differences based on adjusted Tukey-Kramer pairwise comparisons. 
Table 1. Maximum likelihood estimates of annual probabilities of survival $(\sigma)$ for Taxus floridana stages, based on results of log-linear analyses. ${ }^{*}$

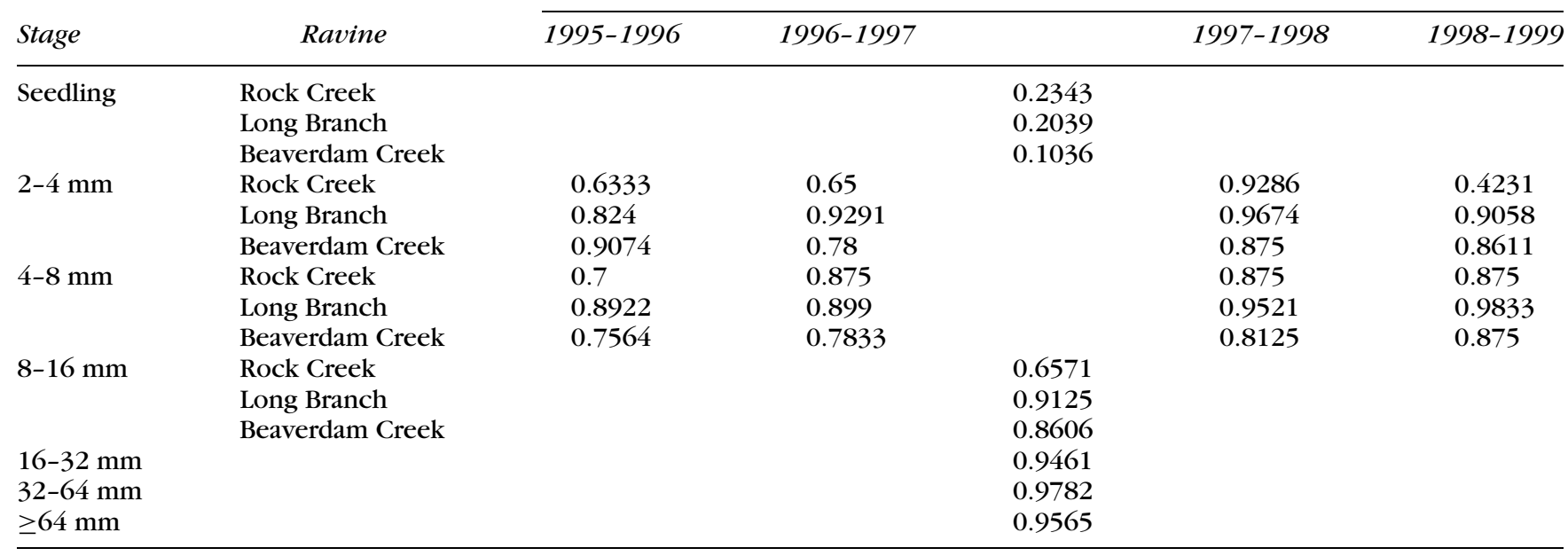

*Spatial and/or temporal differences in $\sigma$ are shown where analyses revealed significant differences.

of seedlings, as well as 2- to 4-, 4- to 8-, and 8- to16-mm stems, were significantly affected by ravine $\left(G^{2}=20.4\right.$, $22.9,15.5,11.0$, respectively; $p<0.05$ ). Survival of these stems was highest in Long Branch. Fates of 2- to 4- and 4- to 8-mm stems were also significantly affected by time $\left(G^{2}=18.0,11.0\right.$, respectively; $\left.p<0.05\right)$. In general, annual survival probabilities increased with increasing stemsize classes, with more spatial and/or temporal variability evident in the smaller stage classes (Table 1). Seedling survival probabilities in Beaverdam Creek were the lowest (0.10), and survival probabilities of 32- to 64-mm stems were the highest $(0.98)$.

\section{STEM GROWTH}

Annual diameter increments of all stems were small, $<1$ $\mathrm{mm}$ per year on average. Stem diameter growth did not differ among ravines $\left(F_{2,27}=1.07, p=0.3581\right)$. Stem diameter growth was estimated at $0.81( \pm 0.06 \mathrm{SE}) \mathrm{mm} /$ year, given by the overall slope coefficient, and ranged from 0.1 $\mathrm{mm}$ /year to approximately $4 \mathrm{~mm}$ /year.

\section{Stochastic Matrix Models}

The stochastic growth rate, $\log \lambda_{s}$, was $<0$ for all three populations of T. floridana (Fig. 3), based on our computed annual transition matrices (Table 2). Values ranged from $-0.0375 \pm 0.0311$ in Rock Creek, to $-0.0370 \pm$ 0.0377 in Beaverdam Creek, to $-0.0260 \pm 0.0296$ in Long Branch, the last of which was generally characterized by consistently higher values of growth and stasis entries in the 2- to 4-, 4- to 8-, and 8- to 16-mm stages. Ninety-five percent confidence intervals barely included 0 in the Long Branch and Beaverdam Creek populations, and did not include 0 in the Rock Creek population. All three popula- tions of T. floridana appear likely to decline in density of stems over time. Estimates of time to extinction ranged from 185 years in Rock Creek, to 187 years in Beaverdam Creek, to 266 years in Long Branch.

For each population, the elasticity of $\lambda_{s}$ was consistently highest for stasis rates of large individuals, particularly those between 32 and $64 \mathrm{~mm}$ in diameter (Fig. 4). Elasticities of $\lambda_{s}$ to changes in stasis of stems $\leq 32 \mathrm{~mm}$ in diameter generally decreased with progressively smaller stage classes; however, higher elasticities to changes in stasis entries of these stages occurred in Long Branch. Collectively, elasticities of $\lambda_{s}$ to changes in stasis entries of established individuals were highest $(>0.94)$, followed

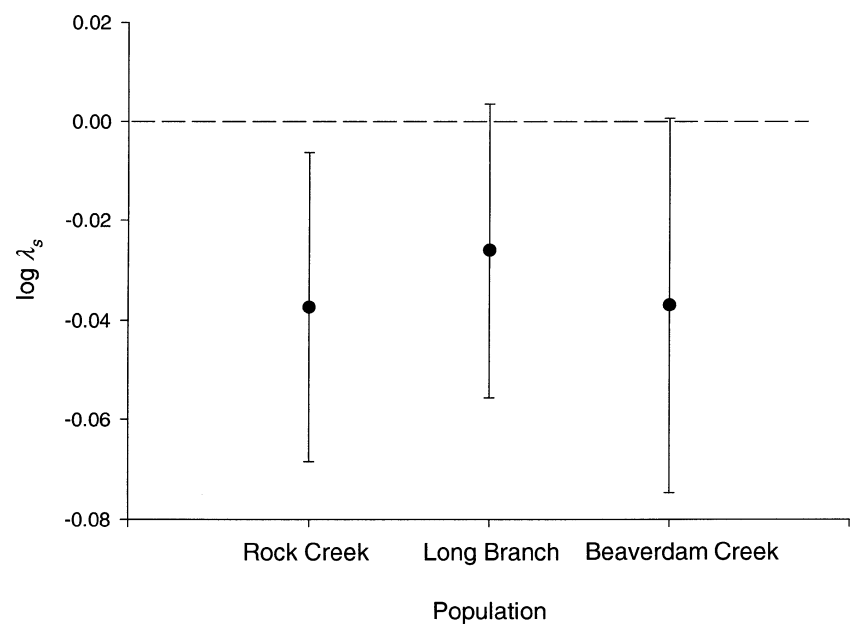

Figure 3. Stochastic growth rates, or $\log \lambda_{\mathrm{s}}, \pm 95 \%$ confidence intervals for sampled populations of Taxus floridana. Values $<0$ indicate declining population sizes. 
Table 2. Annual transition matrices for sampled populations of Taxus floridana. ${ }^{*}$

\begin{tabular}{|c|c|c|c|c|c|c|c|c|c|}
\hline \multicolumn{10}{|l|}{ Rock Creek } \\
\hline sdlg1 & 0 & 0 & 0 & 0 & 0 & 0 & 4.287 & 8.574 & 17.148 \\
\hline sdlg2 & 0.2343 & 0 & 0 & 0 & 0 & 0 & 0 & 0 & 0 \\
\hline sdlg3 & 0 & 0.2343 & 0 & 0 & 0 & 0 & 0 & 0 & 0 \\
\hline $8-16$ & 0 & 0 & 0 & 0 & 0.0625 & 0.6515 & 0 & 0 & 0 \\
\hline $16-32$ & 0 & 0 & 0 & 0 & 0 & 0.0056 & 0.9189 & 0 & 0 \\
\hline $32-64$ & 0 & 0 & 0 & 0 & 0 & 0 & 0.0272 & 0.9625 & 0 \\
\hline $64+$ & 0 & 0 & 0 & 0 & 0 & 0 & 0 & 0.0157 & 0.9565 \\
\hline \multicolumn{10}{|c|}{ 1996-1997 } \\
\hline $8-16$ & 0 & 0 & 0 & 0 & 0.1342 & 0.6515 & 0 & 0 & 0 \\
\hline $16-32$ & 0 & 0 & 0 & 0 & 0 & 0.0056 & 0.9189 & 0 & 0 \\
\hline $32-64$ & 0 & 0 & 0 & 0 & 0 & 0 & 0.0272 & 0.9625 & 0 \\
\hline $64+$ & 0 & 0 & 0 & 0 & 0 & 0 & 0 & 0.0157 & 0.9565 \\
\hline \multicolumn{10}{|c|}{ 1997-1998 } \\
\hline sdlg1 & 0 & 0 & 0 & 0 & 0 & 0 & 0.354 & 0.708 & 1.416 \\
\hline sdlg2 & 0.2343 & 0 & 0 & 0 & 0 & 0 & 0 & 0 & 0 \\
\hline sdlg3 & 0 & 0.2343 & 0 & 0 & 0 & 0 & 0 & 0 & 0 \\
\hline $2-4$ & 0 & 0 & 0.2343 & 0.572 & 0 & 0 & 0 & 0 & 0 \\
\hline $4-8$ & 0 & 0 & 0 & 0.3566 & 0.7408 & 0 & 0 & 0 & 0 \\
\hline $8-16$ & 0 & 0 & 0 & 0 & 0.1342 & 0.6515 & 0 & 0 & 0 \\
\hline $16-32$ & 0 & 0 & 0 & 0 & 0 & 0.0056 & 0.9189 & 0 & 0 \\
\hline \multicolumn{10}{|c|}{ 1998-1999 } \\
\hline $8-16$ & 0 & 0 & 0 & 0 & 0.1342 & 0.6515 & 0 & 0 & 0 \\
\hline $16-32$ & 0 & 0 & 0 & 0 & 0 & 0.0056 & 0.9189 & 0 & 0 \\
\hline $32-64$ & 0 & 0 & 0 & 0 & 0 & 0 & 0.0272 & 0.9625 & 0 \\
\hline $64+$ & 0 & 0 & 0 & 0 & 0 & 0 & 0 & 0.0157 & 0.9565 \\
\hline \multicolumn{10}{|c|}{ 1995-1996 } \\
\hline sdlg1 & 0 & 0 & 0 & 0 & 0 & 0 & 4.287 & 8.574 & 17.148 \\
\hline sdlg2 & 0.2039 & 0 & 0 & 0 & 0 & 0 & 0 & 0 & 0 \\
\hline sdlg3 & 0 & 0.2039 & 0 & 0 & 0 & 0 & 0 & 0 & 0 \\
\hline $2-4$ & 0 & 0 & 0.2039 & 0.536 & 0 & 0 & 0 & 0 & 0 \\
\hline $4-8$ & 0 & 0 & 0 & 0.288 & 0.7493 & 0 & 0 & 0 & 0 \\
\hline $8-16$ & 0 & 0 & 0 & 0 & 0.1429 & 0.8528 & 0 & 0 & 0 \\
\hline $16-32$ & 0 & 0 & 0 & 0 & 0 & 0.0597 & 0.9189 & 0 & 0 \\
\hline $32-64$ & 0 & 0 & 0 & 0 & 0 & 0 & 0.0272 & 0.9625 & 0 \\
\hline $64+$ & 0 & 0 & 0 & 0 & 0 & 0 & 0 & 0.0157 & 0.9565 \\
\hline \multicolumn{10}{|c|}{ 1996-1997 } \\
\hline sdlg1 & 0 & 0 & 0 & 0 & 0 & 0 & 0.552 & 1.103 & 2.207 \\
\hline sdlg2 & 0.2039 & 0 & 0 & 0 & 0 & 0 & 0 & 0 & 0 \\
\hline sdlg3 & 0 & 0.2039 & 0 & 0 & 0 & 0 & 0 & 0 & 0 \\
\hline $2-4$ & 0 & 0 & 0.2039 & 0.5722 & 0 & 0 & 0 & 0 & 0 \\
\hline $4-8$ & 0 & 0 & 0 & 0.3569 & 0.7526 & 0 & 0 & 0 & 0 \\
\hline $8-16$ & 0 & 0 & 0 & 0 & 0.1464 & 0.8528 & 0 & 0 & 0 \\
\hline $16-32$ & 0 & 0 & 0 & 0 & 0 & 0.0597 & 0.9189 & 0 & 0 \\
\hline $32-64$ & 0 & 0 & 0 & 0 & 0 & 0 & 0.0272 & 0.9625 & 0 \\
\hline
\end{tabular}


Table 2. (continued)

\begin{tabular}{|c|c|c|c|c|c|c|c|c|c|}
\hline $\begin{array}{l}\text { Site and stage } \\
\text { at time } \mathrm{t}+1\end{array}$ & \multicolumn{9}{|c|}{ Stage at time $\mathrm{t}$} \\
\hline \multicolumn{10}{|c|}{$1997-1998$} \\
\hline sdlg1 & 0 & 0 & 0 & 0 & 0 & 0 & 0.354 & 0.708 & 1.416 \\
\hline sdlg2 & 0.2039 & 0 & 0 & 0 & 0 & 0 & 0 & 0 & 0 \\
\hline sdlg3 & 0 & 0.2039 & 0 & 0 & 0 & 0 & 0 & 0 & 0 \\
\hline $2-4$ & 0 & 0 & 0.2039 & 0.5843 & 0 & 0 & 0 & 0 & 0 \\
\hline $16-32$ & 0 & 0 & 0 & 0 & 0 & 0.0597 & 0.9189 & 0 & 0 \\
\hline $32-64$ & 0 & 0 & 0 & 0 & 0 & 0 & 0.0272 & 0.9625 & 0 \\
\hline $64+$ & 0 & 0 & 0 & 0 & 0 & 0 & 0 & 0.0157 & 0.9565 \\
\hline \multicolumn{10}{|c|}{ 1998-1999 } \\
\hline sdlg1 & 0 & 0 & 0 & 0 & 0 & 0 & 0.152 & 0.304 & 0.609 \\
\hline $16-32$ & 0 & 0 & 0 & 0 & 0 & 0.0597 & 0.9189 & 0 & 0 \\
\hline $32-64$ & 0 & 0 & 0 & 0 & 0 & 0 & 0.0272 & 0.9625 & 0 \\
\hline $64+$ & 0 & 0 & 0 & 0 & 0 & 0 & 0 & 0.0157 & 0.9565 \\
\hline
\end{tabular}

Beaverdam Creek

1995-1996

\begin{tabular}{|c|c|c|c|c|c|c|c|c|c|}
\hline \multirow[b]{2}{*}{ sdlg1 } & & & & & & & & & \\
\hline & 0 & 0 & 0 & 0 & 0 & 0 & 4.287 & 8.574 & 17.148 \\
\hline sdlg2 & 0.1036 & 0 & 0 & 0 & 0 & 0 & 0 & 0 & 0 \\
\hline sdlg3 & 0 & 0.1036 & 0 & 0 & 0 & 0 & 0 & 0 & 0 \\
\hline $2-4$ & 0 & 0 & 0.1036 & 0.5651 & 0 & 0 & 0 & 0 & 0 \\
\hline $4-8$ & 0 & 0 & 0 & 0.3423 & 0.674 & 0 & 0 & 0 & 0 \\
\hline $8-16$ & 0 & 0 & 0 & 0 & 0.0824 & 0.8195 & 0 & 0 & 0 \\
\hline $16-32$ & 0 & 0 & 0 & 0 & 0 & 0.0411 & 0.9189 & 0 & 0 \\
\hline $32-64$ & 0 & 0 & 0 & 0 & 0 & 0 & 0.0272 & 0.9625 & 0 \\
\hline $64+$ & 0 & 0 & 0 & 0 & 0 & 0 & 0 & 0.0157 & 0.9565 \\
\hline \multicolumn{10}{|c|}{ 1996-1997 } \\
\hline sdlg1 & 0 & 0 & 0 & 0 & 0 & 0 & 0.552 & 1.103 & 2.207 \\
\hline sdlg2 & 0.1036 & 0 & 0 & 0 & 0 & 0 & 0 & 0 & 0 \\
\hline sdlg3 & 0 & 0.1036 & 0 & 0 & 0 & 0 & 0 & 0 & 0 \\
\hline $2-4$ & 0 & 0 & 0.1036 & 0.5195 & 0 & 0 & 0 & 0 & 0 \\
\hline $4-8$ & 0 & 0 & 0 & 0.2605 & 0.6904 & 0 & 0 & 0 & 0 \\
\hline $8-16$ & 0 & 0 & 0 & 0 & 0.0929 & 0.8195 & 0 & 0 & 0 \\
\hline $16-32$ & 0 & 0 & 0 & 0 & 0 & 0.0411 & 0.9189 & 0 & 0 \\
\hline $32-64$ & 0 & 0 & 0 & 0 & 0 & 0 & 0.0272 & 0.9625 & 0 \\
\hline $64+$ & 0 & 0 & 0 & 0 & 0 & 0 & 0 & 0.0157 & 0.9565 \\
\hline \multicolumn{10}{|c|}{ 1997-1998 } \\
\hline sdlg1 & 0 & 0 & 0 & 0 & 0 & 0 & 0.354 & 0.708 & 1.416 \\
\hline sdlg2 & 0.1036 & 0 & 0 & 0 & 0 & 0 & 0 & 0 & 0 \\
\hline sdlg3 & 0 & 0.1036 & 0 & 0 & 0 & 0 & 0 & 0 & 0 \\
\hline $2-4$ & 0 & 0 & 0.1036 & 0.5541 & 0 & 0 & 0 & 0 & 0 \\
\hline $4-8$ & 0 & 0 & 0 & 0.3209 & 0.7073 & 0 & 0 & 0 & 0 \\
\hline $8-16$ & 0 & 0 & 0 & 0 & 0.1052 & 0.8195 & 0 & 0 & 0 \\
\hline $16-32$ & 0 & 0 & 0 & 0 & 0 & 0.0411 & 0.9189 & 0 & 0 \\
\hline $32-64$ & 0 & 0 & 0 & 0 & 0 & 0 & 0.0272 & 0.9625 & 0 \\
\hline $64+$ & 0 & 0 & 0 & 0 & 0 & 0 & 0 & 0.0157 & 0.9565 \\
\hline \multicolumn{10}{|c|}{ 1998-1999 } \\
\hline sdlg1 & 0 & 0 & 0 & 0 & 0 & 0 & 0.152 & 0.304 & 0.609 \\
\hline sdlg2 & 0.1036 & 0 & 0 & 0 & 0 & 0 & 0 & 0 & 0 \\
\hline sdlg3 & 0 & 0.1036 & 0 & 0 & 0 & 0 & 0 & 0 & 0 \\
\hline $2-4$ & 0 & 0 & 0.1036 & 0.5493 & 0 & 0 & 0 & 0 & 0 \\
\hline $4-8$ & 0 & 0 & 0 & 0.3118 & 0.7408 & 0 & 0 & 0 & 0 \\
\hline $8-16$ & 0 & 0 & 0 & 0 & 0.1342 & 0.8195 & 0 & 0 & 0 \\
\hline $16-32$ & 0 & 0 & 0 & 0 & 0 & 0.0411 & 0.9189 & 0 & 0 \\
\hline $32-64$ & 0 & 0 & 0 & 0 & 0 & 0 & 0.0272 & 0.9625 & 0 \\
\hline $64+$ & 0 & 0 & 0 & 0 & 0 & 0 & 0 & 0.0157 & 0.9565 \\
\hline
\end{tabular}

*Stages, except for seedling (sdlg) stages 1-3, are expressed in millimeters. 


\section{a) Rock Creek}

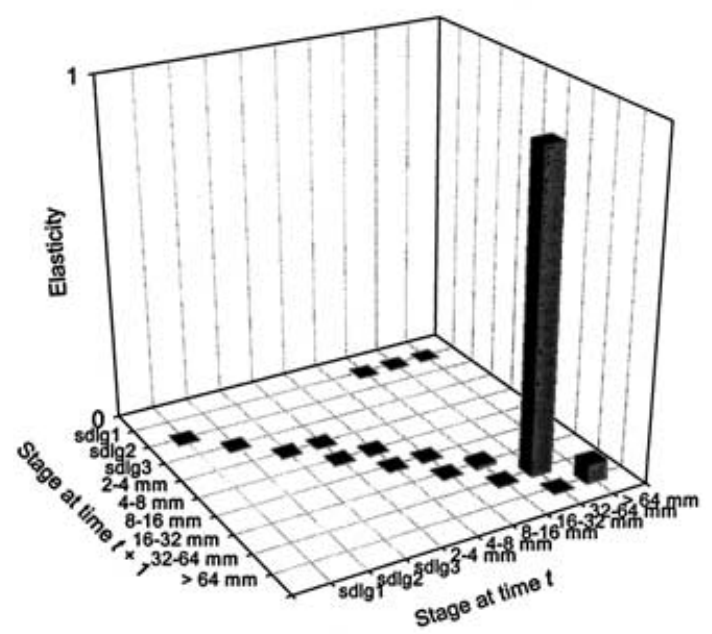

\section{b) Long Branch}

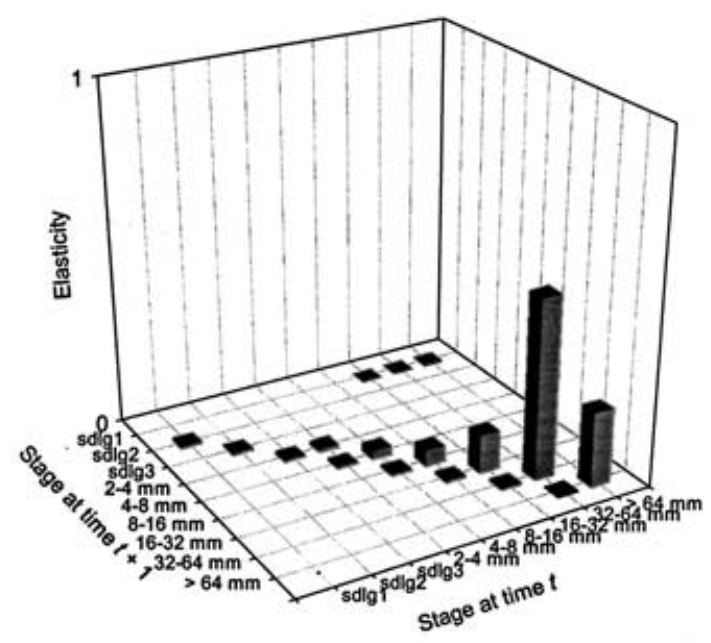

\section{c) Beaverdam Creek}

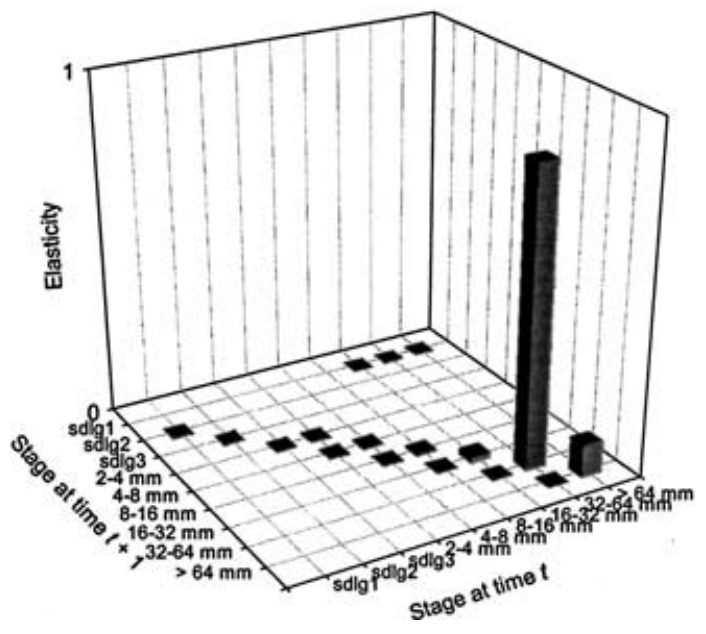

by those associated with changes in growth transitions of established individuals. Elasticities of $\lambda_{s}$ to changes in seedling growth and fertility transitions were even lower.

Occasional episodes of high recruitment (resulting from high fertility), like those observed during the 19951996 interval, had little effect on stochastic growth rates and times to extinction. Removing the year of high recruitment from our models had the greatest, yet minimal, effect on the Long Branch population, and it resulted in a decrease in $\log \lambda_{s}$ to -0.0322 and a decrease in the time to extinction to 215 years. Increasing fertility entries from the high-fertility 1995-1996 matrix by an additional order of magnitude resulted in population declines. With such episodes occurring on average once every 4 years, changes in population growth rates and times to extinction were negligible in the Rock Creek and Beaverdam Creek populations. In the Long Branch population, however, stochastic growth rates did begin to approach $0\left(\log \lambda_{s}=-0.0023 \pm 0.0506\right)$, and times to extinction increased by approximately one order of magnitude $\left(T_{q}=3004\right.$ years).

\section{Discussion}

Does the demography of Taxus floridana differ from that of other tree species? Our population models based on 4 years of demographic data project declining Taxus floridana populations across the range of the species. Such projected declines occur even though survival probabilities increase as stem size increases, reaching values close to 1.0 in the largest size classes. Similar demographic characteristics have been documented for a number of slowgrowing, long-lived trees, including both overstory and understory species (Enright \& Watson 1991; Busing \& Spies 1995; Abe et al. 1998; Batista et al. 1998; Zuidema \& Boot 2002). These species share a survival pattern with T. floridana: as stem size increases, survival probabilities generally increase to high levels, close to 1.0 (Harcombe 1987; Lieberman \& Lieberman 1987; Cipollini et al. 1994; Condit et al. 1995; Abe et al. 1998; Schwartz et al. 2000). Thus, T. floridana resembles other forest tree species because it has population growth rates close to unity and exhibits extended periods of gradual population declines (Silvertown et al. 1993).

Figure 4. Elasticity of $\lambda_{\mathrm{s}}$ to changes in transition for populations (a-c) of Taxus floridana (sdlg, seedling). Elasticities associated with stasis of reproductive stems are highest in each population, and elasticities associated with stasis of nonreproductive stems are bigher in Long Branch than in Rock Creek and Beaverdam Creek. 
Are the declines in T. floridana populations different from those of other long-lived, slow-growing forest trees? Populations of T. floridana have occurred in the Apalachicola Bluffs ravine forests for at least 10,000 years, most of this time disjunct from other populations of Taxus (Platt \& Schwartz 1990). Populations of T. floridana have been persistent and have not been declining continuously for this period of time. Kwit et al. (1998) suggest that the present mesic midslope habitat of T. floridana may have changed within the past two centuries (see also Delcourt \& Delcourt 1977; Schwartz 1994). Such habitat changes may have negatively influenced vital attributes, producing long, slow declines in densities not likely to be even transiently reversed.

A multiple-approach conservation strategy will be needed to preserve long-lived, slow-growing tree populations that, like T. floridana, occur only within restricted areas and predicted to be in slow decline as a result of anthropogenic habitat changes. First, because populations are small, protecting large areas with a broad range of sizes of established plants would decrease the chances of increased mortality of reproductive adults, which would result in much more rapid population declines. Second, proactive management efforts could be focused on generating environmental conditions that increase the survival of established juveniles, especially in populations where juveniles are experiencing higher mortality than that observed in more "healthy" populations. Such an approach might be most useful in the Rock Creek and Beaverdam Creek populations of T. floridana. Juvenile survival was lower in these two populations than in the Long Branch population, where elasticities were somewhat more distributed among life-history transitions, suggesting greater conservation flexibility.

Large changes in juvenile stasis and growth might be feasible from a management perspective. The low elasticities associated with juvenile stems should not preclude a long-term management focus on these stages (cf. Silvertown et al. 1996; de Kroon et al. 2000). Juveniles should be appropriate targets for study of how management options that change environmental conditions might influence matrix-model projections (e.g., effects of deer browsing, light gaps, and fires on growth and survival, and passive clonal growth of prereproductive stages). Efforts to increase seedling production or survival, both of which have been studied in other species of Taxus (Hulme 1996; Minore et al. 1996; Rikhari et al. 1998), are not likely to increase population growth appreciably. In our study, these transitions had the lowest elasticities and minimal impact on population growth rates, and they would likely be difficult to manipulate via management actions. This does not mean, however, that periods of drastically increased seedling recruitment or survival would not promote the persistence of such populations (Mangel \& Tier 1994; Eriksson 1996).
We propose that demographic analyses of slow-growing, long-lived species should be conducted so that conservation actions might be instituted before populations reach states from which recovery might not be possible. Numerous demographic studies of rare plants, primarily herbs, have led to conservation protocols (Menges 1990; Oostermeijer et al. 1996; Allphin \& Harper 1997; Kephart \& Paladino 1997; Floyd \& Ranker 1998; QuintanaAscencio et al. 1998). Proactive conservation measures for rare, slow-growing, long-lived trees need to be more diverse and should target life-history stages that have traditionally been assumed not to contribute greatly to population growth rates.

\section{Acknowledgments}

The authors thank P. Drewa, J. Redwine, B. Platt, L. Derungs, and J. Thaxton for assistance in the field. We thank T. Doyle for his assistance with the analysis of tree ring growth. We are especially thankful to $\mathrm{C}$. Bristol, the people affiliated with Torreya State Park, and The Nature Conservancy (Florida Chapter) for access to study sites. M. Blackwell, J. Denslow, J. Geaghan, W. Batista, S. Tuljapurkar, and M. Cain all made helpful comments and provided important suggestions in the development of the manuscript. We also thank G. Oostermeijer, M. Schwartz, and $S$. Higgins for their valuable comments and input. This research was funded by a grant from the Florida Division of Forestry's Florida Plant Conservation Program.

\section{Literature Cited}

Abe, S., T. Nakashizuka, and H. Tanaka. 1998. Effects of canopy gaps on the demography of the subcanopy tree Styrax obassia. Journal of Vegetation Science 9:787-796.

Agresti, A. 1990. Categorical data analysis. Wiley, New York.

Agresti, A. 1996. An introduction to categorical data analysis. Wiley, New York.

Allphin, L., and K. T. Harper. 1997. Demography and life history characteristics of the rare kachina daisy (Erigeron kachinensis, Asteraceae). American Midland Naturalist 138:109-120.

Barrett, S. C. H., and J. B. Kohn. 1991. Genetic and evolutionary consequences of small population size in plants: implications for conservation. Pages 3-30 in D. A. Falk and K. E. Holsinger, editors. Genetics and conservation of rare plants. Oxford University Press, New York.

Batista, W. B., and W. J. Platt. 1997. An old-growth definition for southern mixed hardwood forests. General technical report SRS-9. U.S. Forest Service Southern Research Station, Asheville, North Carolina.

Batista, W. B., W. J. Platt, and R. E. Macchiavelli. 1998. Demography of a shade-tolerant tree (Fagus grandifolia) in a hurricane-disturbed forest. Ecology 79:38-53.

Benton, T. G., and A. Grant. 1999. Elasticity analysis as an important tool in evolutionary and population ecology. Trends in Ecology \& Evolution 14:467-471.

Busing, R. T., and T. A. Spies. 1995. Modeling the population dynamics of Pacific yew. Research note PNW-RN-515. U.S. Forest Service Pacific Northwest Research Station, Portland, Oregon. 
Cardel, Y., V. Rico-Gray, J. G. Garcia-Franco, and L. B. Thien. 1997. Ecological status of Beaucarnea gracilis, an endemic species of the semiarid Tehuacan Valley, Mexico. Conservation Biology 11:367374.

Caswell, H. 2001. Matrix population models. 2nd edition. Sinauer Associates, Sunderland, Massachusetts.

Cipollini, M. L., D. A. Wallace-Senft, and D. F. Whigham. 1994. A model of patch dynamics, seed dispersal, and sex ratio in the dioecious shrub Lindera benzoin (Lauraceae). Journal of Ecology 82:621-633.

Clewell, A. F. 1986. Natural setting and vegetation of the Florida panhandle. COESAM/PDEI-86/001. Contract DACW01-77-C-0104. U.S. Army Corps of Engineers, Mobile, Alabama.

Condit, R., S. P. Hubbell, and R. B. Foster. 1995. Mortality rates of 205 Neotropical tree and shrub species and the impact of a severe drought. Ecological Monographs 65:419-439.

de Kroon, H., J. van Groenendael, and J. Ehrlén. 2000. Elasticities: a review of methods and model limitations. Ecology 81:607-618.

Delcourt, H. R., and P. A. Delcourt. 1977. Presettlement magnolia-beech climax of the Gulf coastal plain: quantitative evidence from the Apalachicola River bluffs, north-central Florida. Ecology 58:10851093.

Enright, N. J., and A. D. Watson. 1991. A matrix population model analysis for the tropical tree, Araucaria cunninghamii. Australian Journal of Ecology 16:507-520.

Eriksson, O. 1996. Regional dynamics of plants: a review of evidence for remnant, source-sink and metapopulations. Oikos 77:248-258.

Floyd, S. K., and T. A. Ranker. 1998. Analysis of a transition matrix model for Guara neomexicana ssp. coloradensis (Onagraceae) reveals spatial and temporal demographic variability. International Journal of Plant Sciences 159:853-863.

Frankel, D. H., and M. E. Soulé. 1981. Conservation and evolution. Cambridge University Press, Cambridge, United Kingdom.

Harcombe, P. A. 1987. Tree life tables. BioScience 37:557-568.

Huenneke, L. F., and P. L. Marks. 1987. Stem dynamics of the shrub Alnus incana ssp. rugosa: transition matrix models. Ecology 68:12341242.

Hulme, P. E. 1996. Natural regeneration of yew (Taxus baccata L.): microsite, seed or herbivore limitation. Journal of Ecology 84:853861

Kephart, S. R., and C. Paladino. 1997. Demographic change and micorhabitat variability in a grassland endemic, Silene douglasii var. oraria (Caryophyllaceae). American Journal of Botany 84:179-189.

Kwit, C., M. W. Schwartz, W. J. Platt, and J. P. Geaghan. 1998. The distribution of tree species in steepheads of the Apalachicola River Bluffs, Florida. Journal of the Torrey Botanical Society 125:309-318.

Lieberman, D., and M. Lieberman. 1987. Forest tree growth and dynamics at La Selva, Costa Rica (1969-1982). Journal of Tropical Ecology 3:347-358

Littell, R. C., G. A. Milliken, W. W. Stroup, and R. D. Wolfinger. 1996. SAS system for mixed models. SAS Institute, Cary, North Carolina.

Mangel, M., and C. Tier. 1994. Four facts every conservation biologist should know about persistence. Ecology 75:607-614.

Marks, P. L., and P. A. Harcombe. 1981. Forest vegetation of the Big Thicket, southeast Texas. Ecological Monographs 51:287-305.

Means, D. B. 1975. Competitive exclusion along a habitat gradient between two species of salamanders (Desmognathus) in western Florida. Journal of Biogeography 2:253-263.

Menges, E. S. 1990. Population viability analysis for an endangered plant. Conservation Biology 4:52-62.

Minore, D., H. G. Weatherly, and M. Cartmill. 1996. Seeds, seedlings, and growth of the Pacific yew (Taxus brevifolia). Northwest Science 70:223-229.

Nekola, J. C. 1999. Paleorefugia and neorefugia: the influence of colonization history on community pattern and process. Ecology 80:2459-2473

Neter, J., W. Wasserman, and M. H. Kutner. 1990. Applied linear statistical models. 3rd edition. Irwin, Burr Ridge, Illinois.
Oostermeijer, J. G. B., M. L. Brugman, E. R. de Boer, and H. C. M. den Nijs. 1996. Temporal and spatial variation in the demography of Gentiana pneumonanthe, a rare perennial herb. Journal of Ecology 84:153166.

Platt, W. J. 1999. Southeastern pine savannas. Pages 23-51 in R. C. Anderson, J. S. Fralish, and J. Baskin, editors. The savanna, barren, and rock outcrop communities of North America. Cambridge University Press, Cambridge, United Kingdom.

Platt, W. J., and S. M. Hermann. 1986. Relationships between dispersal syndrome and characteristics of populations of trees in a mixedspecies forest. Pages 309-321 in A. Estrada, T. H. Fleming, C. VasquesYanes, and R. Dirzo, editors. Frugivores and seed dispersal. Dr. W. Junk, Dordrecht, The Netherlands.

Platt, W. J., and M. W. Schwartz. 1990. Temperate hardwood forests. Pages 194-229 in R. Myers and J. Ewell, editors. Ecosystems of Florida. University of Central Florida Press, Orlando.

Quintana-Ascencio P. F., R. W. Dolan, and E. S. Menges. 1998. Hypericum cumulicola demography in unoccupied and occupied Florida scrub patches with different time-since-fire. Journal of Ecology 86:640651.

Rabinowitz, D. 1981. Seven forms of rarity. Pages 205-217 in H. Synge, editor. The biological aspects of rare plant conservation. Wiley, New York.

Rabinowitz, D., S. Cairns, and T. Dillon. 1986. Seven forms of rarity and their frequency in the flora of the British Isles. Pages 182-204 in M. E. Soulé, editor. Conservation biology: the science of scarcity and diversity. Sinauer Associates, Sunderland, Massachusetts.

Redmond, A. M. 1984. Population ecology of Taxus floridana, a passively cloning dioecious tree. M.S. thesis. Florida State University, Tallahassee.

Rikhari, H. C., L. M. S. Palni, S. Sharma, and S. K. Nandi. 1998. Himalayan yew: stand structure, canopy damage, regeneration and conservation strategy. Environmental Conservation 25:334-341.

Roovers, L. M., and A. J. Rebertus. 1993. Stand dynamics and conservation of an old-growth Engelmann spruce-subalpine fir forest in Colorado. Natural Areas Journal 13:256-267.

Schemske, D. W., B. C. Husband, M. H. Ruckelshaus, C. Goodwillie, I. M. Parker, and J. G. Bishop. 1994. Evaluating approaches to the conservation of rare and endangered plants. Ecology 75:584606.

Schwartz, M. W. 1994. Natural distribution and abundance of forest species and communities in northern Florida. Ecology 75:687-705.

Schwartz, M. W., and S. M. Hermann. 1993. The continuing population decline of Torreya taxifolia Arn. Bulletin of the Torrey Botanical Club 120:275-286.

Schwartz, M. W., and S. M. Hermann. 1999. Is slow growth of the endangered Torreya taxifolia (Arn.) normal? Journal of the Torrey Botanical Society 126:307-312.

Schwartz, M. W., S. M. Hermann, and C. S. Vogel. 1995. The catastrophic loss of Torreya taxifolia: assessing environmental induction of disease hypotheses. Ecological Applications 5:501-516.

Schwartz, M. W., S. M. Hermann, and P. J. Van Mantgem. 2000. Population persistence in Florida torreya: comparing modeled projections of a declining coniferous tree. Conservation Biology 14:1023-1033.

Silvertown, J., M. Franco, I. Pisanty, and A. Mendoza. 1993. Comparative plant demography: relative importance of life-cycle components to the finite rate of increase in woody and herbaceous perennials. Journal of Ecology 81: 465-476.

Silvertown, J., M. Franco, and E. Menges. 1996. Interpretation of elasticity matrices as an aid to the management of plant populations for conservation. Conservation Biology 10: 591-597.

Stephenson, N. L. 1994. Long-term dynamics of sequoia populations: implications for managing a pioneer species. Pages $56-63$ in P. S Aune, editor. Proceedings of The Conference, Giant Sequoias: their place in the ecosystem and society. General technical report PSWGTR-151. U.S. Forest Service, Albany, California.

Stephenson, N. L. 1996. Ecology and management of giant sequoia 
groves. Pages 1431-1467 in Sierra Nevada ecosystem project: final report to Congress. Volume II, section V. Center for Water and Wildland Resources, University of California, Davis.

The MathWorks. 2001. MATLAB. Version 6. The MathWorks, Natick, Massachusetts.

U.S. Fish and Wildlife Service (USFWS). 1981. A distribution survey of the populations of Taxus floridana and Torreya taxifolia in Florida. Unpublished report. Contract 13-16-0003-81-069.
USFWS, Atlanta, Georgia.

White, D. A. 1987. An American beech-dominated original growth forest in southeast Louisiana. Bulletin of the Torrey Botanical Club 114:127-133.

Zuidema, P. A., and R. G. A. Boot. 2002. Demography of the Brazil nut tree (Bertholletia excelsa) in the Bolivian Amazon: impact of seed extraction on recruitment and population dynamics. Journal of Tropical Ecology 18:1-31.

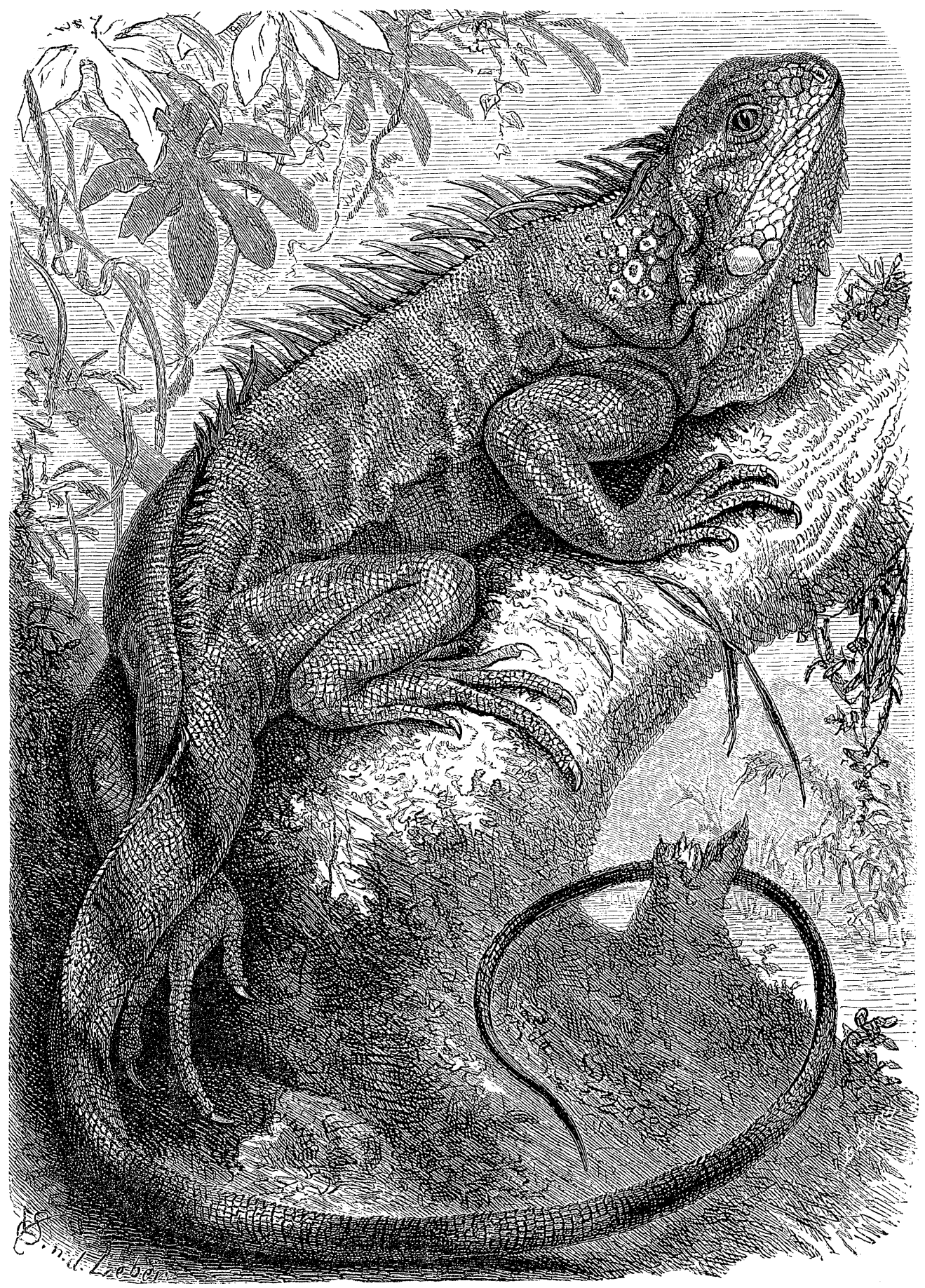

